\title{
NOVÉ ZPŮSOBY OCHRANY OSOB SE ZDRAVOTNÍM POSTIŽENÍM V PRACOVNĚPRÁVNÍCH VZTAZÍCH DE LEGE FERENDA*
}

\author{
VLADIMÍR KREIŽA
}

\begin{abstract}
Improving the Standard of Prohibition of Discrimination Based on Disability in the Field of Employment Relationships de Lege Ferenda

Expecting increasing pressure on the labour market in the Czech Republic caused by covid-19 pandemic effects, with regard to the briefly evaluated standard of the protection of people with disabilities from discrimination in the field of employment relationships in the Czech Republic, the aim of this text is to identify the legal reasons of this state and especially to provide de lege ferenda proposals that could lead to an increase of the standard of the prohibition of discrimination based on disability in the field of employment relationships.

The author proposes inter alia the introduction of the institute of shared burden of proof into administrative proceedings and the introduction of the possibility of demanding the conclusion of an employment contract in a civil action.
\end{abstract}

Keywords: discrimination; labour law; disability

Klíčová slova: diskriminace; pracovní právo; zdravotní postižení

DOI: $10.14712 / 23366478.2021 .20$

\section{1. ÚVOD}

Míra nezaměstnanosti v České republice zůstává i v době pandemie onemocnění covid-19 obecně relativně velmi nízká. Podle odhadu Českého statistického úřadu byla obecná míra nezaměstnanosti ve 4. čtvrtletí $20203 \%$, ve 4. čtvrtletí 2019, tedy ještě před výskytem prvního oficiálně potvrzeného případu onemocnění covid-19 na našem území, byla obecná míra nezaměstnanosti $2 \%{ }^{1}$

Vzhledem k tomu, že nezaměstnanost v ČR dosud nějak závratně neroste, lze předpokládat, že tento stav je důsledkem mj. i poměrně robustního systému státních dotačních a stimulačních programů, a to ekonomických i právních.

* Tento text byl zpracován v návaznosti na diplomovou práci Zákaz diskriminace osob se zdravotním postižením v pracovněprávních vztazích obhájené autorem tohoto článku na katedře pracovního práva a práva sociálního zabezpečení Právnické fakulty Univerzity Karlovy v roce 2020.

1 Zaměstnanost, nezaměstnanost. In: Český statistický úřad [online]. 8. 2. 2021 [cit. 2021-02-13]. Dostupné na: https://www.czso.cz/csu/czso/zamestnanost_nezamestnanost_prace. 
Je však třeba se legislativně připravit na situaci, kdy tento efekt z nějakého důvodu odpadne. Stejně tak platí, že česká právní úprava zákazu diskriminace osob se zdravotním postižením v pracovněprávních vztazích poskytuje řadu prostoru pro zlepšení. Současná krize tak může být příležitostí k inventuře př́ílušné právní úpravy a provedení návazných změn, ke kterým v běžné době nemusí být taková vůle.

Antidiskriminační právo chránící osoby se zdravotním postižením prošlo v předminulém desetiletí zásadními legislativními změnami, jako je zejm. přijetí Rámcové směrnice, ${ }^{2}$ vznik Úmluvy ${ }^{3}$ a AntiDZ. ${ }^{4}$ Následkem tohoto rozvoje antidiskriminačních norem mohlo v minulém desetiletí přirozeně dojít $\mathrm{k}$,,projudikování“ těchto předpisů českou i unijní soudní praxí. I tak však empirický stav ochrany osob se zdravotním postižením v pracovněprávních vztazích není dobrý.

\section{KE STAVU REALITY DODRŽOVÁNÍ ZÁKAZU DISKRIMINACE OSOB SE ZDRAVOTNÍM POSTIŽENIIM V PRACOVNĚPRÁVNÍCH VZTAZÍCH}

Ze statistických údajů, konkrétně Výběrového šetření osob se zdravotním postižením - 2018 Českého statistického úřadu, vyplývá, že se 10,4 \% osob se zdravotním postižením setkalo v zaměstnání s diskriminací. ${ }^{5}$

Podezřelé rovněž je, že 38,9 \% zaměstnanců muselo kvůli svému zdravotnímu postižení změnit zaměstnání. 6

Velký problém může pro lidi se zdravotním postižením znamenat zaměstnání vůbec získat - 40,3 \% respondentů v rámci výše uvedeného šetření totiž uvedlo, že měli určité nebo velké potíže s hledáním zaměstnání, ${ }^{7}$ přitom obecná míra nezaměstnanosti v roce 2018 byla $2,2 \%{ }^{8}$ Přríčinou může být skutečnost, že v roce 2018 bylo uchazečů

2 Směrnice Rady 2000/78/ES ze dne 27. listopadu 2000, kterou se stanoví obecný rámec pro rovné zacházení v zaměstnání a povolání.

3 Úmluva o právech osob se zdravotním postižením, vyhlášená jako sdělení Ministerstva zahraničních věcí č. 10/2010 Sb. m. s., o sjednání Úmluvy o právech osob se zdravotním postižením.

4 Zákon č. 198/2009 Sb., o rovném zacházení a o právních prostředcích ochrany před diskriminací a o změně některých zákonů (antidiskriminační zákon).

5 Pro účely Výběrového šetření osob se zdravotním postižením - 2018 se osobou se zdravotním postižením rozumí taková osoba, která , uvedla, že je kvůli zdravotním problémům nejméně po dobu posledních 6 měsíců omezena v činnostech, které lidé obvykle dělají nebo pobírá invalidní di̊chod, příspěvek na péči nebo př́spěvek na mobilitu nebo má status osoby se zdravotním postižením (zákon o zaměstnanosti) nebo je držitelem průkazu osoby se zdravotním postižením “. Vymezení tak neodpovídá AntiDZ. Srov. Výběrové šetření osob se zdravotním postižením - 2018 [online]. 2018 [cit. 2021-02-13]. Dostupné na: https://www.czso .cz/documents/10180/90600407/26000619_m.pdf/564f1d0b-2386-4d6e-b0f0-4889bb8377d5?version=1.1.

6 Pracující osoby se zdravotním postižením podle změny práce a diskriminace v práci kvůli zdravotnímu postižení [online]. [cit. 2021-02-13]. Dostupné na: https://www.czso.cz/documents/10180 /90600407/26000619504.pdf/ebdef64a-3d01-427b-a21d-9993a94eba3b?version=1.1.

7 Pracující osoby se zdravotním postižením podle potíží s hledáním současného zaměstnání a pohlaví [online]. [cit. 2021-02-13]. Dostupné na: https://www.czso.cz/documents/10180/90600407/26000619502 .pdf/61329361-8a99-4ff0-9e6e-dec1419a4ab5?version=1.1.

8 Základní charakteristiky ekonomického postavení obyvatelstva ve věku 15 a více let. In: Český statistický úřad: veřejná databáze [online]. [cit. 2021-02-13]. Dostupné na: https://vdb.czso.cz/vdbvo2/faces/cs /index.jsf?page=vystup-objekt-vyhledavani\&vyhltext=Z\%C3\%A1kladn\%C3\% AD+charakteristiky 
o zaměstnání se zdravotním postižením vedených v evidenci Úřadu práce ČR relativně hodně (38 268 z celkem 231534 uchazečů o zaměstnání, tedy 16,5\%), ${ }^{9}$ nicméně pracovních míst pro osoby se zdravotním postižením bylo v evidenci Úřadu práce ČR relativně málo, pouze 13514 , přičemž pro osoby bez zdravotního postižení bylo v evidenci Úřadu práce ČR 310896 volných pracovních míst. ${ }^{10}$

Připadalo-li v roce 2018 na jednoho uchazeče o zaměstnání bez zdravotního postižení přibližně 1,3 volného pracovního místa, pro uchazeče se zdravotním postižením to již bylo jen 0,35 volného pracovního místa.

V roce 2018 tak $81,4 \%$ osob se zdravotním postižením vůbec nepracovalo. ${ }^{11,12}$

Nelze ale s jistotou říci, jak velký ve skutečnosti problém diskriminace je. Ze zdrojů, jako jsou statistiky a analytické zprávy veřejného ochránce práv, př́ípadně komparací s daty z jiných členských států, sice lze obecně dovozovat slabou vynutitelnost zákazu diskriminace (a tedy lze předpokládat, že velká část diskriminace zůstává neodhalena), vědecky však nelze vyloučit ani možnost, že se v ČR diskriminace lidí se zdravotním postižením v pracovněprávních vztazích jednoduše př́liš neděje.

\section{VEŘEJNOPRÁVNÍ OCHRANA PŘED DISKRIMINACÍ}

V př́ípadě veřejnoprávní ochrany poskytované primárně orgány inspekce práce je problematické celkové pojetí jejich činnosti, které tyto orgány samy v zásadě pojmenovávají jako prevenční. Prevence založená na nízkých pokutách a na jakémsi napomenutí či pokusu o osvětu v př́ípadě zjištění diskriminace je však neúčinná, jak dokládá zvyšující se počet podnětů i vysoký počet zjištěných porušení zákonů. ${ }^{13}$

Veřejný ochránce práv jakožto druhý orgán poskytující veřejnoprávní ochranu nemá k dispozici sankční nástroje, sankcionování ostatně ani není jeho úloha, která spočívá v systémovém monitorování, individuálním poradenství a informování veřejnosti, vlády a dalších orgánů. Nelze proto od veřejného ochránce práv očekávat, že vynutitelnost

+ekonomick\%C3\%A9ho+postaven\%C3\%AD\&bkvt=WsOha2xhZG7DrSBjaGFyYWt0ZXJpc3Rpa

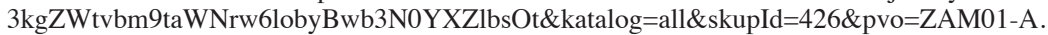

9 Na rozdíl od Výběrového šetření osob se zdravotním postižením - 2018 jsou v rámci dat od Úřadu práce ČR osoby se zdravotním postižením vymezeny podle ZZ, tedy úžeji než v př́ípadě Výběrového šetření osob se zdravotním postižením - 2018.

10 Podíl nezaměstnaných osob, pracovní místa v evidenci Úřadu práce. In: Český statistický uurad: veřejná databáze [online]. [cit. 2021-02-13]. Dostupné na: https://vdb.czso.cz/vdbvo2/faces/cs/index.jsf?page =vystupobjekt\&pvo=ZAM09\&f=TABULKA\& $\mathrm{z}=\mathrm{T} \& \mathrm{katalog}=30853 \& \mathrm{str}=\mathrm{v} 170 \& \mathrm{c}=\mathrm{v} 3 \sim 3 \_$RP2018.

11 Osoby se zdravotním postižením podle pracovního úvazku, pohlaví a věku. In: Český statistický úrad [online]. [cit. 2021-02-13]. Dostupné na: https://www.czso.cz/documents/10180/90600407/26000619501 .pdf/ca1e453f-9354-4189-bf12-361c8479f169?version=1.1.

12 Pro srovnání např. v Rakousku je podíl lidí bez zaměstnání se zdravotním postižením v produktivním věku ve stejném období pouze 41,5\%. Viz níže Sonderbericht der Volksanwaltschaft 2019: Keine Chance auf Arbeit - Die Realität von Menschen mit Behinderung. In: Volksanwaltschaft [online]. 10. 12. 2019 [cit. 2021-02-13]. Dostupné na: https://volksanwaltschaft.gv.at/downloads/30c01/Sonderbericht\%20MmB\%20 $2019 \% 2029.11 .19 .11$

13 Roční souhrnná zpráva o výsledcích kontrolních akcí za rok 2019. In: Státní úráa inspekce práce [online]. [cit. 2021-02-13]. Dostupné na: http://www.suip.cz/_files/suip-ff57ab22e75b0e506741d3b6dace9e9c /suip_rocni-souhrnna-zprava-o-vysledcichkontrolnich-akci-za-rok-2019.pdf. 
zákazu diskriminace nějak zásadně zvýší. Tento úkol leží na orgánech inspekce práce a na soudním systému.

\section{SOUKROMOPRÁVNÍ OCHRANA PŘED DISKRIMINACÍ}

Právě rozhodování obecných soudů, které poskytují soukromoprávní ochranu obětem diskriminace, se však jeví jako nejproblematičtější. Autor by očekával, že právě soudy budou případy diskriminace ze všech orgánů řešit po právní stránce nejlépe. Koneckonců, nejedná se o zcela novou problematiku, ke které navíc existuje poměrně všeobjímající judikatura Soudního dvora EU, jejíž přínos spočívá mj. v definici zdravotního postižení. ${ }^{14}$ Česká právní úprava obdobnou vlastní definici nemá.

Autor se v rámci následujícího výkladu dopustí určité generalizace, nicméně založené na zkoumání všech rozhodnutí obecných soudů ve věcech zákazu diskriminace osob se zdravotním postižením v pracovněprávních vztazích zahájených v období od účinnosti AntiDZ (1. záŕí 2009) do 31. prosince 2019.15

Celkově lze říci, že současným výkladem principu děleného důkazního břemene ve smyslu § 133a OSR ${ }^{16}$ v podstatě nemůže dojít k soudnímu uznání, že se diskriminace člověka se zdravotním postižením stala.

Problémem českých soudů totiž je, že nežrídka kdy nerespektují principy aplikace děleného důkazního břemene podle $§ 133$ a OSŘ. Tento princip spočívá ve dvou krocích. ${ }^{17}$

Žalobce musí prokázat znevýhodňující zacházení (nap̌̌. za použití osoby ve srovnatelném postavení či situaci - komparátora ${ }^{18}$ - či v prŕípadě neprrímé diskriminace statistiky či jinak) a zdravotní postižení, o němž tvrdí, že je příčinou znevýhodňujícího zacházení.

14 Soudní dvůr EU považuje od 1. prosince 2016, tedy od doby vydání rozsudku Soudního dvora (tř̌etího senátu) ze dne 1. prosince 2016 ve věci C-395/15 (Mohamed Daouidi v. Bootes Plus SL), ve spojení s předcházejícími rozsudky, zdravotní postižení za „omezení vyplývající především z dlouhodobých fyzických, duševních nebo psychických postižení, které v interakci s různými překážkami může bránit plnému a účinnému zapojení dotčené osoby do profesního života na rovnoprávném základě s ostatními pracovníky, je-li toto omezení dlouhodobé, přičemž mezi nepřimé di̊kazy toho, že zdravotní postižení je dlouhodobé, náleží zejména skutečnost, že v okamžiku diskriminačního skutku nelze jasně očekávat, že stav neschopnosti dotčené osoby skončí v krátkodobém horizontu, nebo že se doba trvání tohoto stavu neschopnosti může před návratem dotčené osoby do práce podstatně prodloužit. Tuto dlouhodobost je třeba dovodit z dokumentů a zpráv, které se týkaji stavu osoby a byly vypracovány na základě aktuálních lékařských a vědeckých poznatků a údajů, a z dalších objektivních skutečností. "Zdravotním postižením může být v tomto smyslu bez ohledu na zavinění toho, kdo jím trpí, za splnění výše uvedených podmínek i léčitelná nebo neléčitelná nemoc nebo úraz. Viz dále rozsudky Soudního dvora (velkého senátu) ze dne 11. července 2006 ve věci C-13/05 (Sonia Chacón Navas v. Eurest Collectividades); rozsudek Soudního dvora (druhého senátu) ze dne 11. dubna 2013 ve spojených věcech C-335/11 a C-337/11 (HK Danmark); rozsudek Soudního dvora (čtvrtého senátu) ze dne 18. prosince 2014 ve věci C-354/13 (Fag og Arbejde v. Kommunernes Landsforening); rozsudek Soudního dvora (velkého senátu) ze dne 18. března 2014 ve věci C-363/12 (Z. v. A Government Department).

15 Jedná se celkem o sedm soudních sporů. Z nich v žádném řízení žalobce namítající diskriminaci neuspěl. Dvě soudní řízení skončila schválením smíru a dva případy dosud neskončily.

16 Zákon č. 99/1963 Sb., občanský soudní řád.

17 Tento test vychází z výše uvedené judikatury Soudního dvora, obdobně též viz např. nález Ústavního soudu ze dne 12. srpna 2015, sp. zn. III. ÚS 1136/13; nález Ústavního soudu ze dne 26. dubna 2006, sp. zn. Pl. ÚS 37/04; či nález Ústavního soudu ze dne 30. dubna 2009, sp. zn. II. ÚS 1609/08.

18 TOMŠEJ, J. Diskriminace na pracovišti. Praha: Grada Publishing, 2020, s. 17. 
Žalovaný pak prokazuje, že neporušil zásadu rovného zacházení a k diskriminaci nedošlo, tedy že znevýhodňující zacházení bylo založené na objektivních důvodech (nebylo motivováno zdravotním postižením), že žalobce není ve stejném postavení jako komparátor či jinak (např. že poskytnutí přiměřených opatření by pro zaměstnavatele představovalo nepřiměřené zatížení dle $\S 3$ odst. 2 až odst. 4 AntiDZ, či že rozdílné zacházení je nezbytné pro výkon práce podle $\$ 16$ odst. 4 ZP).

Soudy však oba kroky v podstatě spojí dohromady tak, že soud de facto rovnou přejde $\mathrm{k}$ druhému kroku aplikace děleného důkazního břemene. Zanedbání prvního kroku, spočívající $\mathrm{v}$ často nevhodném použití komparátora (komparátorem nemůže být osoba bez zdravotního postižení), a tím pádem nedostatečně prokázané znevýhodňující zacházení, vede $\mathrm{k}$ tomu, že soud rovnou posuzuje př́ípustnost rozdílného zacházení. Zpravidla navíc v obecné rovině, tudíž se neřeší povinnost žalovaného přijmout přiměřená opatření. ${ }^{19}$ Setkat se lze i s překvapivými rozhodnutími, viz rozsudek Nejvyššího soudu, který žalobce-policistu odkázal do režimu správního soudnictví. ${ }^{20}$

Takto provedený test nemůže vzhledem $\mathrm{k}$ řečenému dojít $\mathrm{k}$ jinému závěru, než že se diskriminace nestala.

Obdobné lze říci i o používání definic nebo vymezení vztahu nemoci a zdravotního postižení. Vše je v judikatuře Soudního dvora EU až učebnicově popsáno.

\section{NÁVRH ŘEŠENÍ}

Zvýšení zaměstnanosti lidí se zdravotním postižením a odhalování i tzv. skryté diskriminace ${ }^{21}$ by bylo možné díky rozšrĩrení pravomoci a působnosti orgánů inspekce práce. $V$ př́ípadě podnětu neúspěšného uchazeče o zaměstnání se zdravotním postižením by orgán inspekce práce zaměstnavatele analogicky $\mathrm{k} \S 133 \mathrm{a}$ OSŘ vyzval, aby prokázal, že neporušil zásadu rovného zacházení. Tento princip by měl platit i v době trvání jakéhokoliv pracovního poměru zaměstnance se zdravotním postižením.

Na podkladě př́padného rozhodnutí o přestupku by se pak mohl diskriminovaný uchazeč o zaměstnání či zaměstnanec u soudu žalobou na náhradu při újmě na přirozených právech člověka podle ustanovení § 2956 an. OZ ${ }^{22}$ domáhat na podkladě $§ 10$ AntiDZ náhrady škody a přiměřeného zadostiučinění, včetně odčinění případných

19 Přitom odmítnutí nebo opomenutí přijmout přiměřená opatř̌ení je samo o sobě nepřímou diskriminací (§ 3 odst. 2 AntiDZ).

${ }^{20} \mathrm{~K}$ tomu viz TOMŠEJ, J. HIV ve služebním poměru. In: ŠMÍD, M. Právo na rovné zacházení: deset let antidiskriminačního zákona. Praha: Wolters Kluwer, 2020, s. 154.

21 Judikatura skrytou diskriminaci rozeznává a zakazuje v kontextu zadávání veřejných zakázek, kde je vưči dodavatelům diskriminace rovněž nepř́ípustná. Zde se jedná o takový postup zadavatele, který spočívá v nastavení nepřiměřeně vysokých kvalifikačních kritérií, která de facto vyřazují některé dodavatele, byt' by tito k plnění veřejné zakázky byli objektivně způsobilí. Srov. rozsudek Nejvyššího správního soudu ze dne 5. června 2008, č. j. 1 Afs 20/2008-152. V kontextu AntiDZ či zákoníku práce se pojem skrytá diskriminace neobjevuje, a to ani v teorii. Lze říci, že se jedná o tě̌̌ko zjistitelnou formu diskriminace, kdy jednání může vypadat jako postup v souladu se zákonem, ale ve skutečnosti je motivováno zakázaným diskriminačním důvodem. Např. zaměstnavatel odmítne uchazeče o zaměstnání, aniž by mu sdělil důvod. Skutečným důvodem odmítnutí bylo uchazečovo zdravotní postižení.

22 Zákon č. 89/2012 Sb., občanský zákoník. 
duševních útrap způsobených diskriminačním jednáním a okolností hodných zvláštního zřetele. V případě, že bylo diskriminačním jednáním oběti ublíženo na zdraví, vzniká jí nárok na bolestné, náhradu za ztížení společenského uplatnění a úhradu účelně vynaložených nákladů spojených s léčbou. V případě pracovní neschopnosti jakožto následku diskriminačního jednání lze žalovat i náhradu za ztrátu na výdělku a na důchodu. Náhrada újmy náleží i osobám, které ji pocit’ují jako osobní neštěstí.

Do popředí se tak dostává funkce individuálně i generálně preventivní - odstrašující - a zároveň funkce odměny pro úspěšného žalobce, který se nebál jít s rizikem do neprŕíjemného (a nejistého) sporu. ${ }^{23}$ Funkci odměny pro žalobce je přitom žádoucí posilovat. Od nové úpravy soukromého práva totiž nelze vnímat cíle antidiskriminační žaloby jako automaticky morálně satisfakční. Soudy přiznávané peněžní nároky v případě zjištěné diskriminace jsou ale stále nízké, přibližně 1000 EUR až 2000 EUR. V kontrastu s tím, povinnost případné náhrady nákladů řízení v případě neúspěchu ve věci řadu potenciálních žalobců od podání žaloby spolehlivě odradí ${ }^{24}$

Autor rovněž navrhuje doplnit demonstrativní ustanovení $§ 10$ odst. 1 AntiDZ v tom smyslu, že ten, kdo byl diskriminačním jednáním dotčen, má rovněž právo se u soudu domáhat uzavření pracovní nebo obdobné smlouvy.

Taková úprava AntiDZ by jistě znamenala omezení principu smluvní volnosti, resp. autonomie vůle, jakožto vůdčí zásady soukromého práva. Proti omezení smluvní svobody lze jistě mít řadu připomínek, zejména z liberálních pozic namítat přílišnou regulaci mající za důsledek to, že pracovní smlouva vlastně ztrácí svůj smysl. ${ }^{25}$

De lege lata je však omezení smluvní svobody ve prospěch slabší smluvní strany v pracovním právu naprosto typické a obecně nesouměřitelné s jakýmkoliv jiným soukromoprávním odvětvím. Štangová v tomto kontextu dokonce zařazuje princip omezení smluvní svobody mezi základní principy, na nichž je pracovní právo postaveno. ${ }^{26}$

Zároveň platí, že kontraktační svoboda co do výběru osoby, vưči níž bude právní jednání směřovat (adresáta), je v soukromém právu obecně omezena AntiDZ. ${ }^{27}$

Mezi základní zásady zákoníku práce ${ }^{28}$ patří i rovné zacházení se zaměstnanci a zákaz jejich diskriminace, což je zároveň hodnota, která chrání veřejný pořádek ( $\$ 1 \mathrm{a}$ zákoníku práce). Sám OZ v § 1 odst. 2 vylučuje smluvní volnost tam, kde je v rozporu s dobrými mravy či veřejným pořádkem.

Zároveň je základní zásadou soukromého práva ulpiánovské „, nikomu nelze odepří, co ти ро právu náležî" ( 3 odst. 2 písm.f) OZ), tedy obecné přihlášení se ke spravedlnosti.

23 KÜHN, Z. Nová žaloba podle § 10 antidiskriminačního zákona. Právní rozhledy. 2010, č. 3, s. 77-86.

24 TOMŠEJ, J. Sanction Systems in the Light of EU Directives 2000/43/EC and 2000/78/EC: a Comparative Study of Slovakia, Czechia and Poland. European Equality Law Review. 2020, č. 2 , s. 54.

25 BEZOUŠKA, P. Pracovní právo ve společnosti 21. století. Právní rozhledy. 2008, č. 1, s. 19-22.

26 ŠTANGOVÁ, V. Rovné zacházení a zákaz diskriminace v pracovním právu. Plzeň: Aleš Čeněk, 2010, s. 29.

27 LAVICKÝ, P. § 3 [Zásady soukromého práva]. In: BÍLKOVÁ, J. - ČERNÝ, M. - ČUHELOVÁ, K. DAVID, L. - DÁVID, R. - DOBROVOLNÁ, E. - FOJTÍK, L. - HANDLAR, J. - HAVLAN, P. - HOLEJŠOVSKÝ, J. - HORECKÝ, J. - HULMÁK, M. - HURDÍK, J. - HRDLIČKA, M. - KOUKAL, P. - LASÁK, J. - LAVICKÝ, P. - LAZÍKOVÁ, J. - LEBEDA, M. - PODIVÍNOVÁ, M. K. - PONDIKASOVÁ, T. - RONOVSKÁ, K. - RUBAN, R. - ŠEVČEK, M. - TŮMA, P. - VÍTEK, J. Občanský zákoník. I, Obecná část (\$ 1-654): komentár. Praha: C. H. Beck, 2014, s. 51.

28 Zákon č. 262/2006 Sb., zákoník práce. 
Není koneckonců ani nic na tom, že právo ukládá kontraktační povinnost, aktivní smluvní přímus. Dvořák smluvní prrímus připouští právě v případech, kdy se veřejný zájem spočívající na zájmu veřejného pořádku a zachovávání dobrých mravů ocitá v převaze nad soukromým zájmem, tedy v momentech, kdy právo chrání subjektivní práva za pomoci autoritativní ochrany státu. Mělo by se však jednat o př́ípady, kdy je takový zásah nezbytně nutný. I Ústavní soud dovozuje, že ochrana autonomie vůle nemůže být absolutní a musí ustoupit tam, kde existuje základní právo jiné osoby nebo ústavní princip, anebo jiný ústavně aprobovaný zájem, které jsou způsobilé proporcionálně autonomii vůle omezit (srov. nález Ústavního soudu ze dne 6. listopadu 2007, sp. zn. III. ÚS 3/06). ${ }^{29}$

Kontraktační povinnost se v praxi objevuje v řadě předpisů - poskytovatel platebních služeb má povinnost uzavřít se spotřebitelem na jeho výzvu smlouvu o základním platebním účtu, ${ }^{30}$ vlastník vodovodu nebo kanalizace, popřípadě provozovatel, pokud je k tomu vlastníkem zmocněn, je povinen uzavřít písemnou smlouvu o dodávce vody nebo odvádění odpadních vod s odběratelem ${ }^{31}$ apod. Společným znakem uvedených příkladů je skutečnost, že jakkoliv se jedná o vztahy mezi osobami soukromého práva, jsou z důvodu veřejného zájmu významně právně regulovány. Stejně jako pracovněprávní vztahy.

Lze říci, že se jedná, jako v pracovním právu často, o nelehký úkol sladit princip smluvní volnosti s principem ochrany zaměstnance a nalézt jejich spravedlivý poměr (tzv. princip flexijistoty). ${ }^{32}$

Dalším návrhem je skrze školení inspektorů orgánů inspekce práce, závaznými metodickými pokyny Ministerstva práce a sociálních věcí, personálním posílením orgánů inspekce práce apod. zpř́ísnit postihování diskriminace.

Autor rovněž oceňuje návrh rozšîrené okruhu osob aktivně legitimovaných k podání antidiskriminační žaloby o některé právnické osoby ve smyslu chystané novely AntiDZ. 33

Autor uzavírá, že přijetím výše prezentovaných opatření by se kvalita vynutitelnosti zákazu diskriminace osob se zdravotním postižením v pracovněprávních vztazích mohla zásadně zvýšit a pro futuro ochránit zranitelné účastníky trhu práce v období, kdy tlaky na tento trh zesílí.

Mgr. Vladimír Kreiža

vladimir.kreiza@gmail.com

29 DVOŘÁK, J. § 3 Právo veřejné a soukromé. In: DVOŘÁK, J. - ŠVESTKA, J. - ZUKLÍNOVÁ, M. Občanské právo hmotné. 1, díl první, Obecná část. 2. aktual. a dopl. vyd. Praha: Wolters Kluwer, 2016, s. 35-36.

30 \$210 zákona č. 370/2017 Sb., o platebním styku.

$31 \S 8$ odst. 6 zákona č. 274/2001 Sb., zákon o vodovodech a kanalizacích pro veřejnou potřebu a o změně některých zákonů (zákon o vodovodech a kanalizacích).

32 HŮRKA, P. Ochrana zaměstnance a flexibilita zaměstnávání: princip flexijistoty v českém pracovním právu. Praha: Auditorium, 2009, s. 23.

33 Sněmovní tisk 424: novela z. - antidiskriminační zákon. 